\title{
St Kilda: stone tools, dolerite quarries and long-term survival
}

\author{
ANDREW FLEMING * \\ St Kilda, the little group of islands far offshore from northwest Scotland, was known for \\ its seabird subsistence in the period before its evacuation in 1930. Recent discoveries \\ suggest that the importance of agriculture in the prehistoric period (before the 16th \\ century AD) may have been underestimated.
}

\section{St Kilda and its prehistory}

The St Kilda archipelago lies some $60 \mathrm{~km}$ west of the Western Isles of Scotland $\left(57^{\circ} 49^{\prime} \mathrm{N}\right.$; $08^{\circ} 35^{\prime} \mathrm{W}$ ). Apparently only the main island, Hirta, has been continuously occupied; its population of 36 was evacuated in 1930, much reduced from its highest recorded figure of 180 at the time of Martin Martin's visit in 1697 (Stell \& Harman 1988: 31). The writings of Martin (1698) and various subsequent written accounts and photographs have revealed quite a lot about the islanders' lifeways over the period 1700-1930 (Macgregor 1960; Steel 1975; Maclean 1977). The archaeology of the area most sheltered from the Atlantic gales, around Village Bay, has been well documented in a recent RCAHMS Scotland volume (Stell \& Harman 1988). The landscape is dominated by the ruins of 19th-century buildings, many of them along a 'street', the axis of the village replanned and relocated in 1830 . The people rented allotments within the head dyke which was constructed then. There are also numerous cleitean (anglicized as 'cleits'), corbelled stone and turf buildings used mainly for storage. Many were in place by 1697 (Martin 1698: 59). There are earlier walls and banks, notably north of the 19th-century houses, in the areas just above and below the 1830 head dyke (Stell \& Harman 1988).

The most up-to-date account of St Kilda's prehistory (effectively the period before the mid 16th century) has to rely on evidence from individual sites and finds (Cottam 1979). There are some Norse place-names, and Martin records that three churches once existed in the Village Bay area; two inscribed crosses are incorporated in standing buildings (Harman 1976-7). There is a souterrain, which should date from probably relatively late in the Iron Age (defined broadly, in Scottish terms, as the millennium centred on the BC/AD transition). Numerous 'boat-shaped' stone settings above the 1830 head dyke have been tentatively ascribed to the Bronze Age (Cottam 1979: 46-8). The island of Dun is said to contain the ancient wall of what may have been a prehistoric 'defensive' site. This article presents three discoveries made in August 1994, when I was a member of a conservation work party organized by the National Trust for Scotland, present owners of these islands; they may change current perceptions of St Kilda's prehistory.

\section{Stone tools in the cleits}

The museum in the re-roofed House 3 contains three or four stone tools, including one described (if memory serves) as a possible blade for a hoe or digging implement. Shortly after seeing this, I noticed a lenticular-sectioned piece of stone protruding from the lower part of the turf roof of cleit 55. I picked it out, and saw that it had once been part of a stone implement. A search of cleits in the vicinity soon produced two more broken implements, this time from among the stonework. Speculating that a more systematic search of the cleits might produce a serviceable distribution map of these tools, I started to look further afield. It turned out that the average cleit in the Village Bay area

* Department of Archaeology, University of Wales, Lampeter SA48 7ED, Dyfed, Wales.

Received 28 October 1994, accepted 2 December 1994.

AN'TQUTTY 69 (1995): 25-35 
a

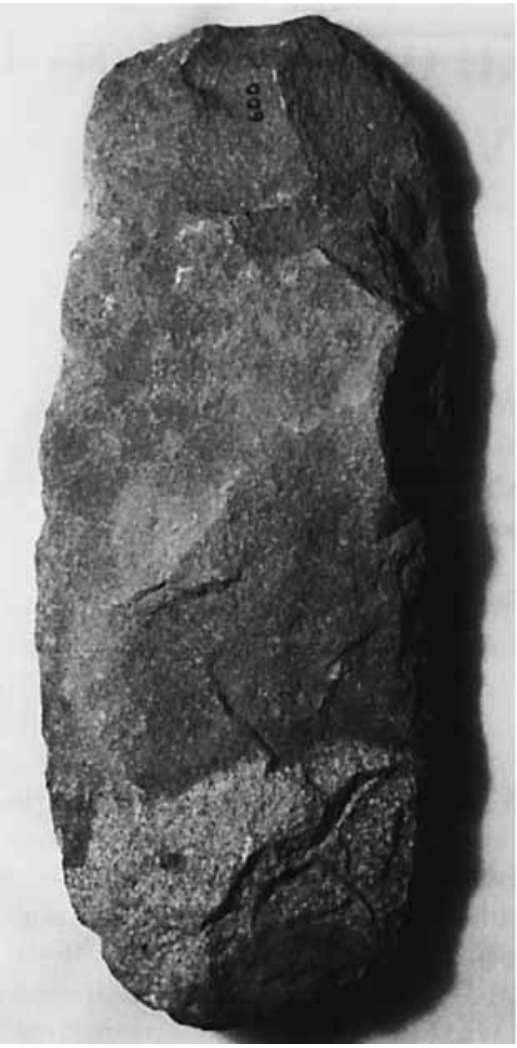

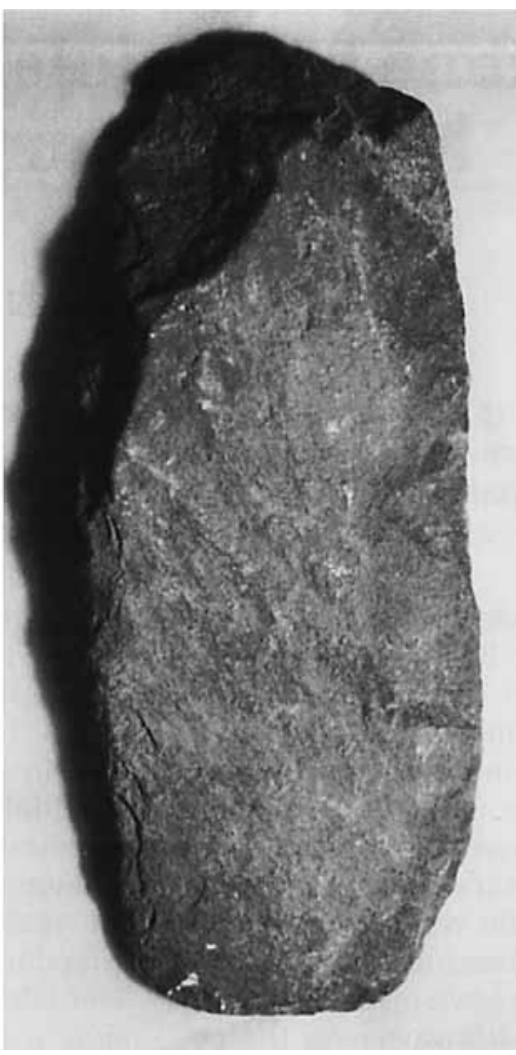

b

FIGURE 1. St Kilda: dolerite implements from the village, now in Kelvingrove Museum, Glasgow.

a \& b. No. 600 (l. $212 \mathrm{~mm}, \max$. w. 90 $\mathrm{mm})$. c. No. 622 (197 x $126 \mathrm{~mm}) . \mathrm{d}$. No. $605(172 \times 126$ $\mathrm{mm}$ ). (Photos: $A$. Fleming.)

C
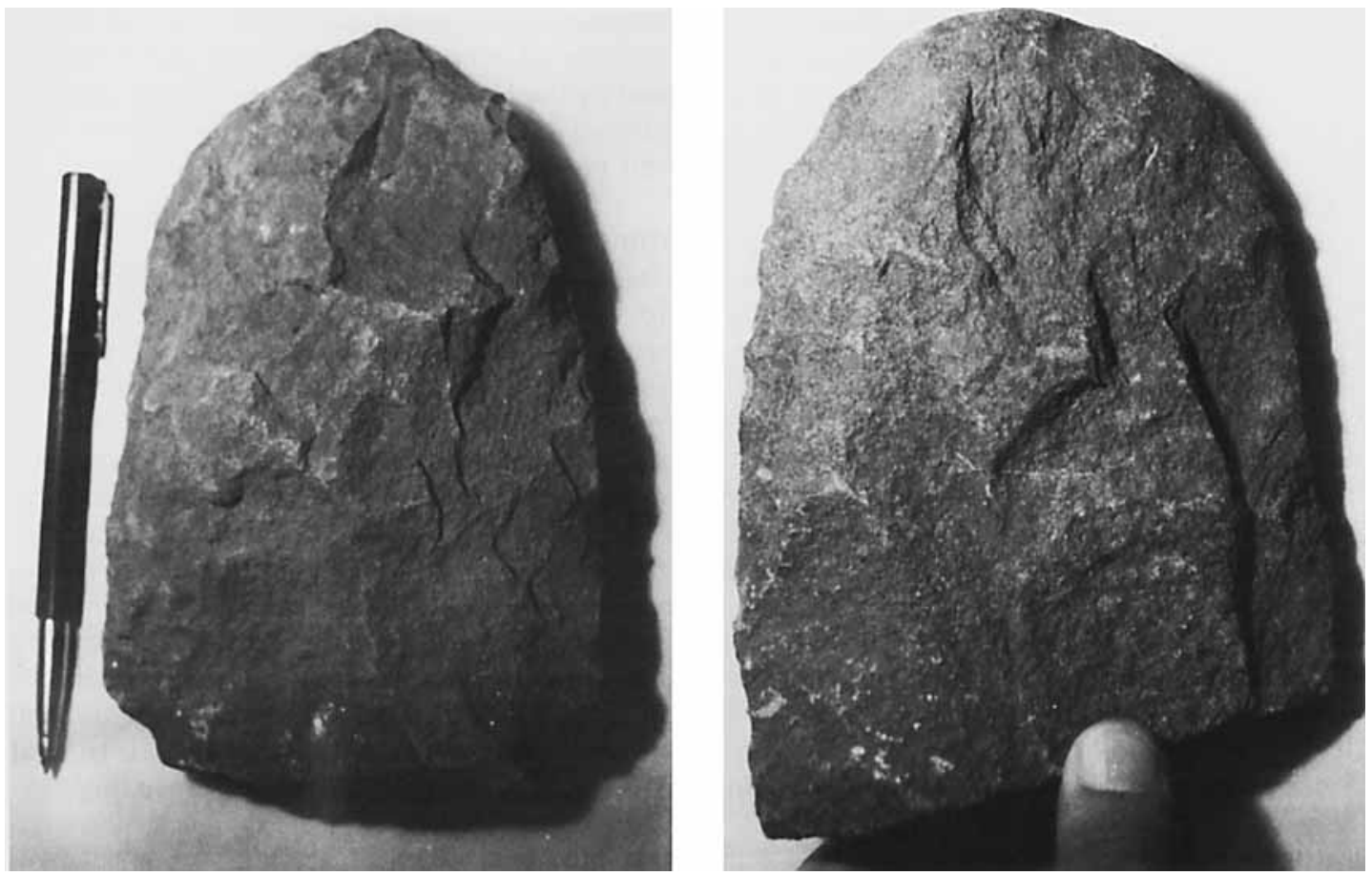


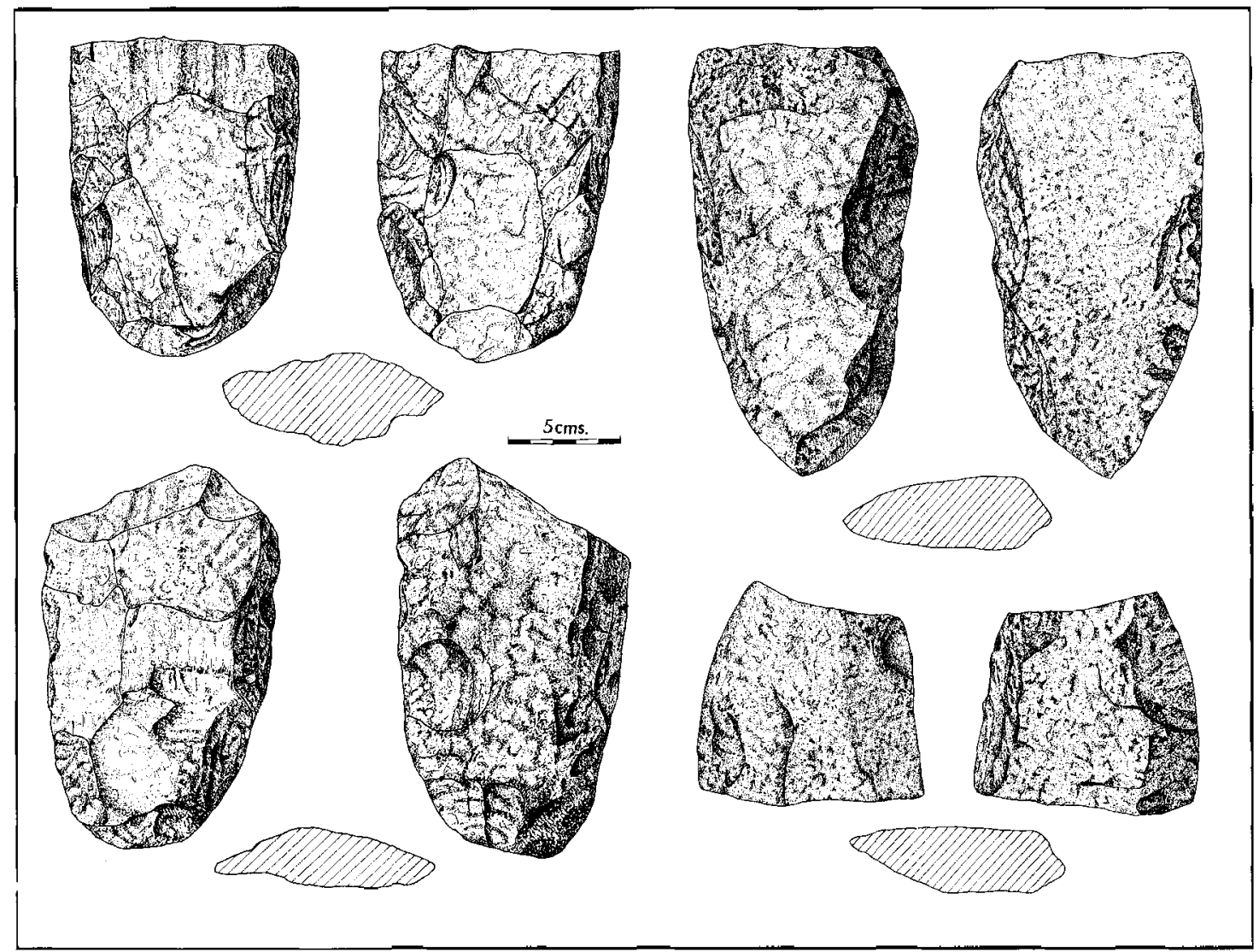

FIGJRE 2. Dolerite implements from cleits 55 and 35.

was quite likely to contain a broken implement. Soon I noticed that broken stone implements also occurred in the walls of black-houses, stone clearance piles and the field walls and consumption dykes of the 19th century (FIGURES 1 \& 2).

Building the cleits required a quantity of small stones, some used as chocks for the larger stones making up the walls. Among these small stones, I could usually find one or two broken implements, noticeable because of their colour. Most of the area within the 1830 head dyke is on acid granophyre -- a stone which appears buff to white depending on the weather conditions. West of the House 14/House 15 boundary (roughly) the native rock is a dark blue or grey dolerite. This contrast shows up well on the storm beach of Village Bay, the yellow-buff/ blue-black transition occurring just east of the ramp for landing-craft (FIGURE 3 ). The broken implements are made of dolerite, and most of their find-spots are in walls and cleits made of granophyre.

These stone implements consist of cores and flakes which have been finished by varying combinations of flaking and pecking or grinding to produce tools which, in cross-section, may be relatively 'rod-like' or more lenticular (FIGURES 1 \& 2). Pecked, somewhat blunt-looking tools are interpretable as hoe-blades or ardtips; others, made on narrower flakes with more secondary retouch, look more like cutting or butchering tools. Many are well made, and symmetrical about their three axes. The implements drawn here are about $25 \mathrm{~cm}$ long by about $10 \mathrm{~cm}$ wide in the middle. The provisional distribution map (FIGURE 3 ) shows them widely distributed within the area enclosed by the 1830 head dyke, with one occurrence beyond it (cleit 145). On the steeper, rockier slopes east and west of cleit 145 , the implements are apparently non-existent or much 


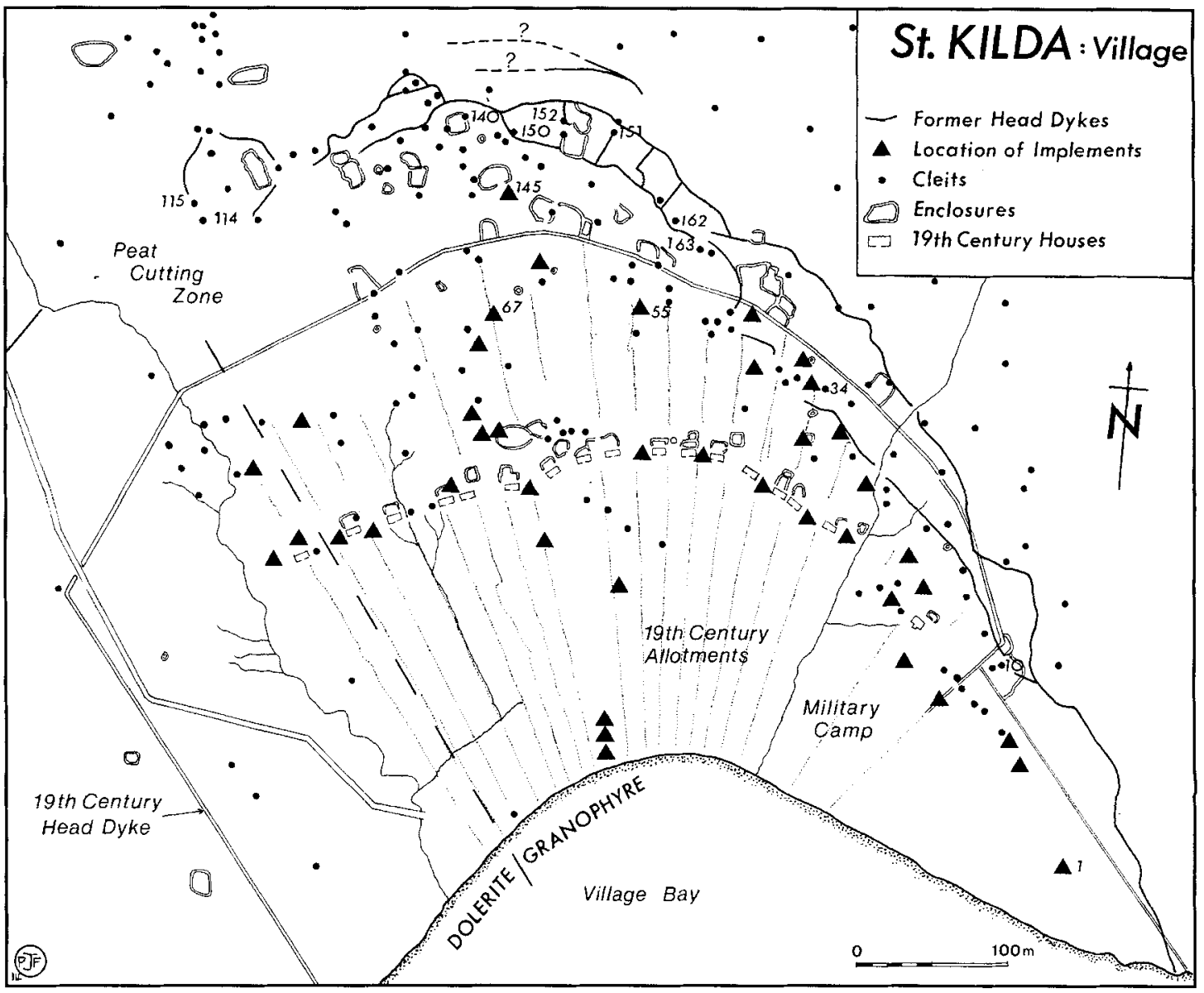

FIGURE 3. Map of village area, to show find-spots of dolerite implements, cleits mentioned in text and the locations of pre-1830 head dykes (after RCHM, positions approximate elsewhere).

rarer, and a search of the stonier area west of cleit 67 also drew a blank. (It is believed (Stell \& Harman 1988: 2; Williamson \& Boyd 1960: $55-66)$ that the zone near cleit 145 was the pre1830 settlement zone; it is sheltered, does not intrude on the more fertile land below, and has easy access to a good water supply.)

\section{Stone quarries}

Knowing that weathered rock would not have been appropriate raw material for such a welldeveloped lithic industry, I began to wonder about sources. It was not necessary to look very far. Southwest of Village Bay, there are extensive dolerite screes on the steep hillside around Clash na Bearnaich, the old name for what is now called the 'Chimney', the steep and narrow grassy defile which divides the rock-face above the screes into two sectors, north and south (see FIGURES 4 \& 5). According to a recent account (Sutherland et al. 1984), frostshattered debris forms a talus above a protalus rampart, both features forming during the cold, tundra conditions of the Loch Lomond interstadial $(11,000-10,000$ b.p.). Grassy vegetation now covers the upper slopes of this 'talus', and the downhill advance of tongues of grass has given the upper edges of the scree a scalloped outline (FIGURE 5). From the village area it appears that there are caves, filled almost to their roofs, in the zone where the top of this grasscovered scree meets the near-vertical rock-faces above. These 'caves' were recognized as artificial in a local story (which, to judge from surface inspection, seems unlikely to be literally true) that islanders used them to hide from 


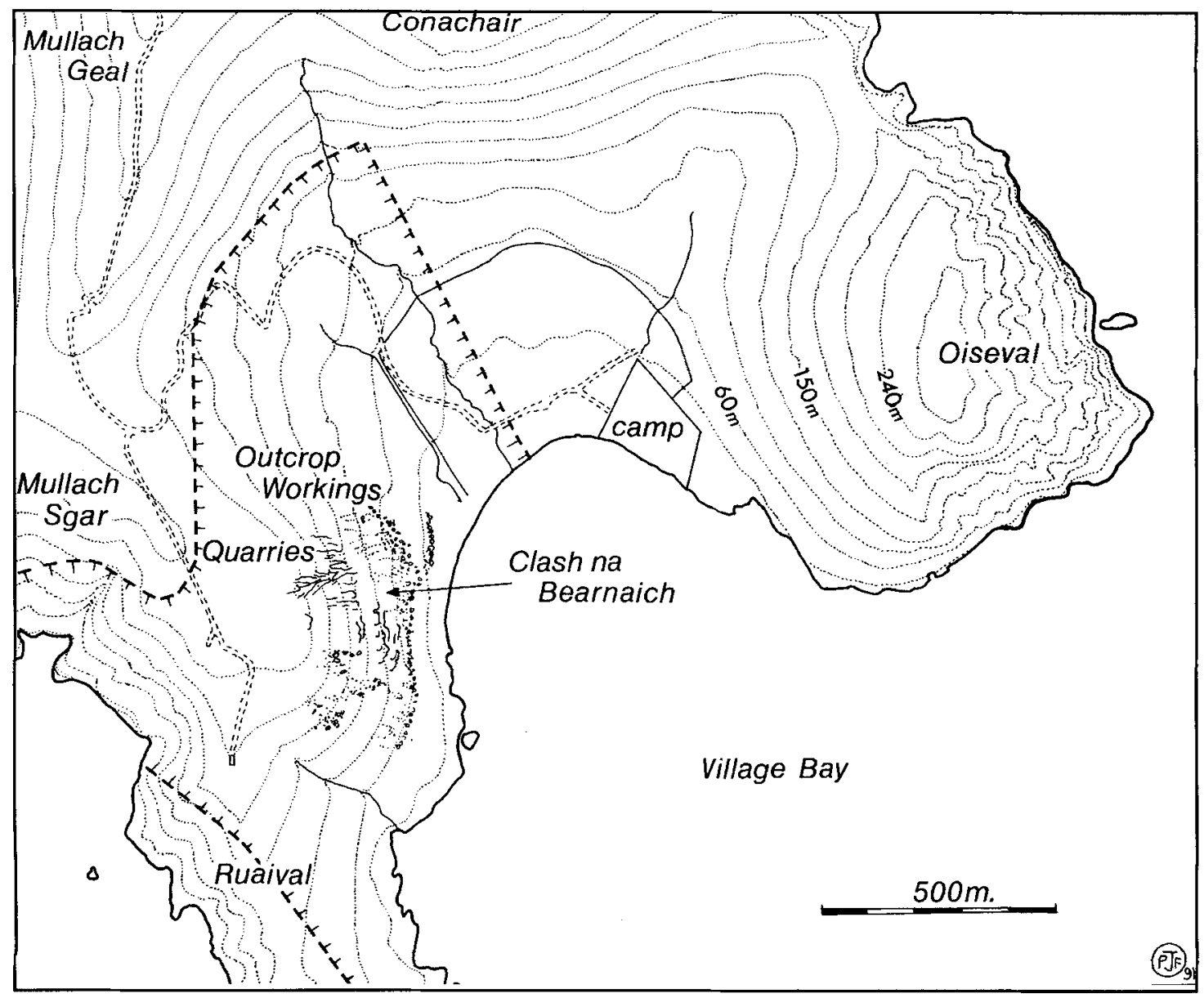

FIGURE 4. Map to show location of Clash na Bearnaich and the area of dolerite.

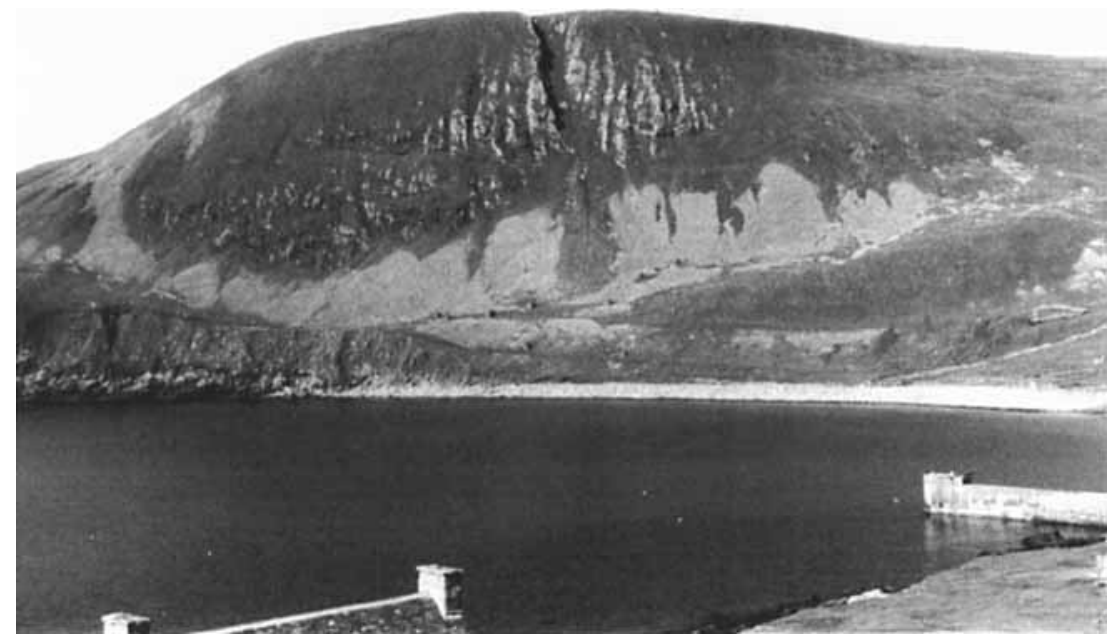

FiguRe 5. Clash na

Bearnaich - general

view from the east. 

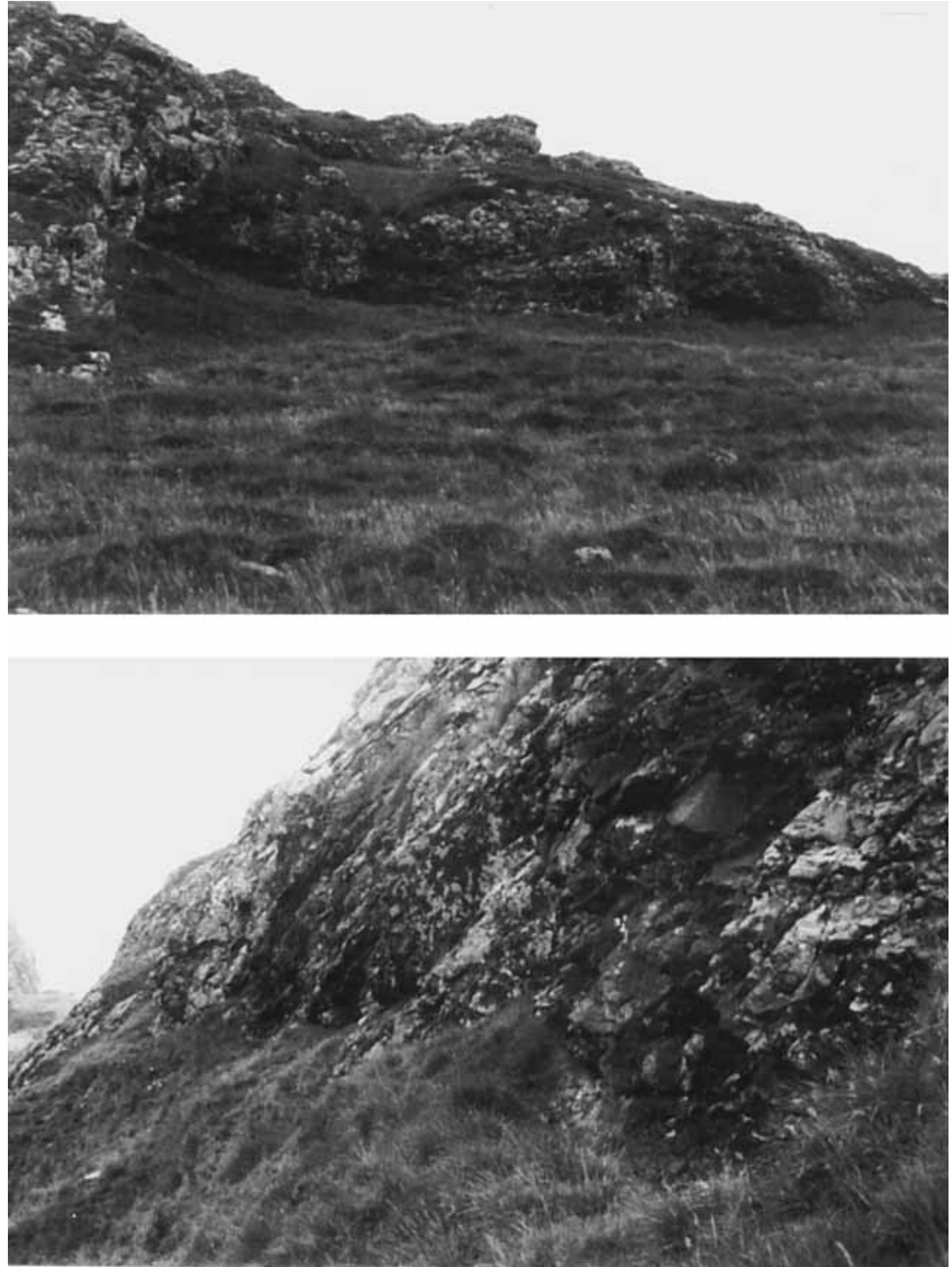

Figure 6. Clash na Bearnaich quarries.
FIGURE 7. Clash na Bearnaich - working face. soldiers looking for Bonnie Prince Charlie (Steel 1975: 32). In fact they look very like the tops of the Neolithic quarries at Great Langdale in Cumbria (Bradley \& Edmonds 1993: plate 4.10) and of site 1 at Creag na Caillich, Perthshire (Edmonds et al. 1992: illus. 9). Closer inspection shows (FIGURES $6 \& 7$ ) that there have indeed been quarry-faces undercutting the dolerite here, on both sides of the Chimney. As one crosses the Chimney at the level of the quarries, it becomes clear that at least two rocky bluffs just above this level, on each side of the Chimney, have also been quarried; a tall rock pinnacle in a vertiginous position south of the Chimney has also been sharply undercut.
Vegetation prevents inspection of the debris immediately below the visible quarry faces. Lower down, where the 'screes' are still exposed, there are flakes and retouched pieces in the upper levels. Eroded hollows just above the upper edges of the screes disclose (where observation is not impeded by oil-spitting fulmar chicks) a soil cover, with some struck flakes embedded in it, above what is clearly quarry waste, with air spaces; the stone gives off a 'ringing' tone when struck. Lower down the screes, in more mixed material, it is possible to recognize flakes and positive and negative bulbs of percussion, and to note in a preliminary fashion two recurrent shapes appa- 
rently belonging to an initial stage in the reduction process: large cushion-like blocks perhaps $30 \mathrm{~cm} \times 20 \mathrm{~cm} \times 10 \mathrm{~cm}$, and thick rod-like shapes $30 \mathrm{~cm}$ in length and $10 \mathrm{~cm}$ in diameter with one or two long flakes taken off. Some of these 'cushions' and 'rods' are found near the base of the screes, where one might expect heavier material to fall.

In general, there is quarry waste, quite a lot of it grass-covered, on the upper slopes, and a higher proportion of natural talus on the midslopes, where weathering has softened the edges of what must have been originally frostfractured stones, many covered in lichens. On the screes at the base of the slopes is a good deal of evidence for stone-working, with large flakes and cores. Presumably the larger boulders which came to rest on the protalus rampart during the Loch Lomond interstadial would have provided implement-making material just as unweathered as that later detached by human agency from the rock-faces above, the heavier blocks of which would also have ended up at the base of the scree.

These screes have quite a complex history. In relatively recent times they must have provided stone for the cleits and small enclosures in the zone near their base, and perhaps also for the $\mathbf{1 8 3 0}$ head dyke further away. There are one or two small walled enclosures among the stones, and a relatively recent wall climbs one scree, breasting the slope at an acute angle to the contour. Clearly, in recent centuries, zones of exposed and covered screes have not been stable; it seems that grass cover is invading both from above and below. The origin of numerous narrow terraces or benches on the screes, running along the contour, needs further investigation.

South of the screes below the rocky bluffs are several large shallow screes, including some which originate from high up on the slopes of Mullach Sgar, above and to the side of the rock faces in which the quarries have been made. These screes include worked material; a few small rock exposures, which also show signs of quarrying, protrude from among the debris, as they do among the main central 'talus' already described. Some at least of this scree material results from quarrying small rock exposures at or near the surface.

Where the rocky bluffs die out to the north of the main screes there has been sporadic quar- rying of dolerite outcrops. Low down the slopes there are one or two patches of weathered, lichen-covered 'talus', which has been turned over to provide stone for nearby cleits. Higher up are small rock exposures which have clearly been quarried, with waste material streaming down the slopes below - numerous chips and some flakes and cores, a few protruding from soil exposed in section, notably by water which descends the slope at wetter times of the year, and probably prevents the soil and grass cover from completely sealing the working areas (FIGURES 8 \& 9). These 'heavily bashed' rock outcrops together with the working debris below them, exposed by water action, are among the the most readily recognizable indications of quarrying at Clash na Bearnaich. It seems that there are more of these small, individual working sites further north at about this level on the hillside, probably extending as far as the zone where the granophyre rock of Conachair takes over. There is also 'hummocky' ground on the less steeply sloping land above the quarrying level described - that is, in the zone between the main rocky bluffs and the modern surfaced road where it climbs to An Blad. This area looks like the zone of open-cast workings behind the Pike of Stickle, in Cumbria (the zone not very well illustrated in Bradley \& Edmonds 1993: plate 4.5). At Great Langdale 'more than one approach to axe making was followed at the sources' (Bradley \& Edmonds 1993: 102).

\section{Discussion}

The quarries and other surface workings at Clash na Bearnaich join a small group of relatively well-preserved stone-working sites for the production of identifiable groups of implements, as well as filling a distributional gap in northwest Scotland (Wickham Jones 1986). These quarries and working sites await further study, along with the implements for which they were developed. Morrison's recent excavations of 'boat-shaped structures' in small cairns at An Lag Bho'n Tuath, outside and to the north of the 1830 head dyke, have produced good examples of these stone implements, including at least one which was deep within cairn material (Morrison pers. comm.). On the basis of mainland parallels for the structures, Morrison believes that they are probably of Bronze Age date, though confirmation is awaited. 
FIGURE 8. Roughouts from outcrop workings.

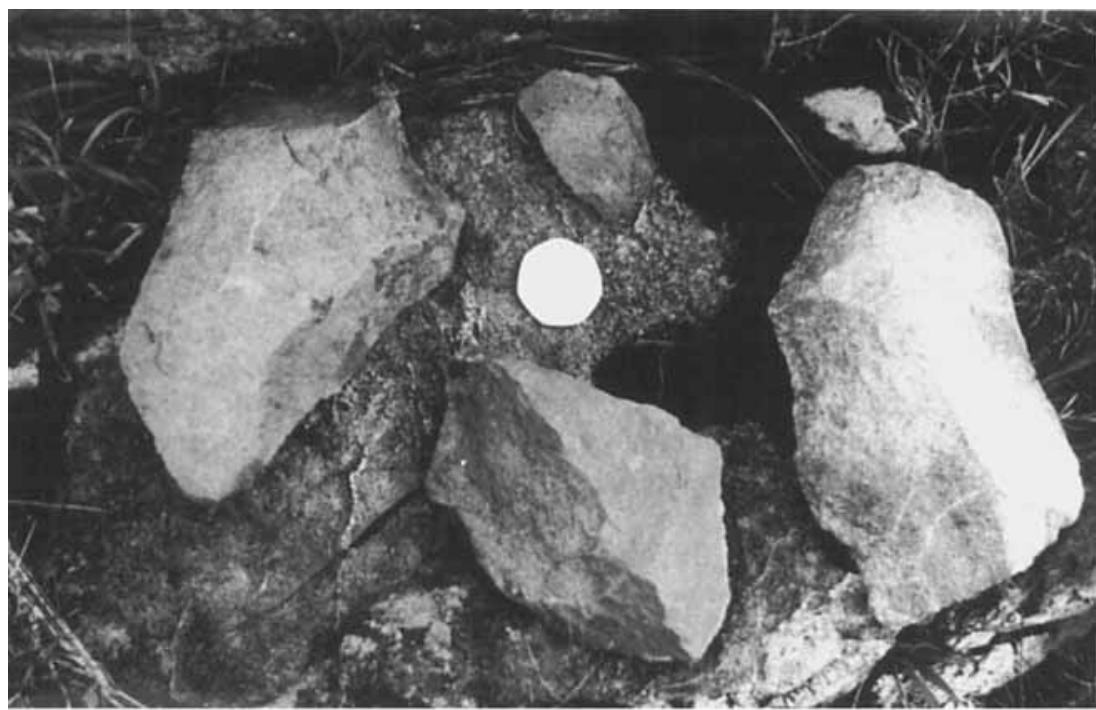

FIGURE 9. A roughout among working debris.

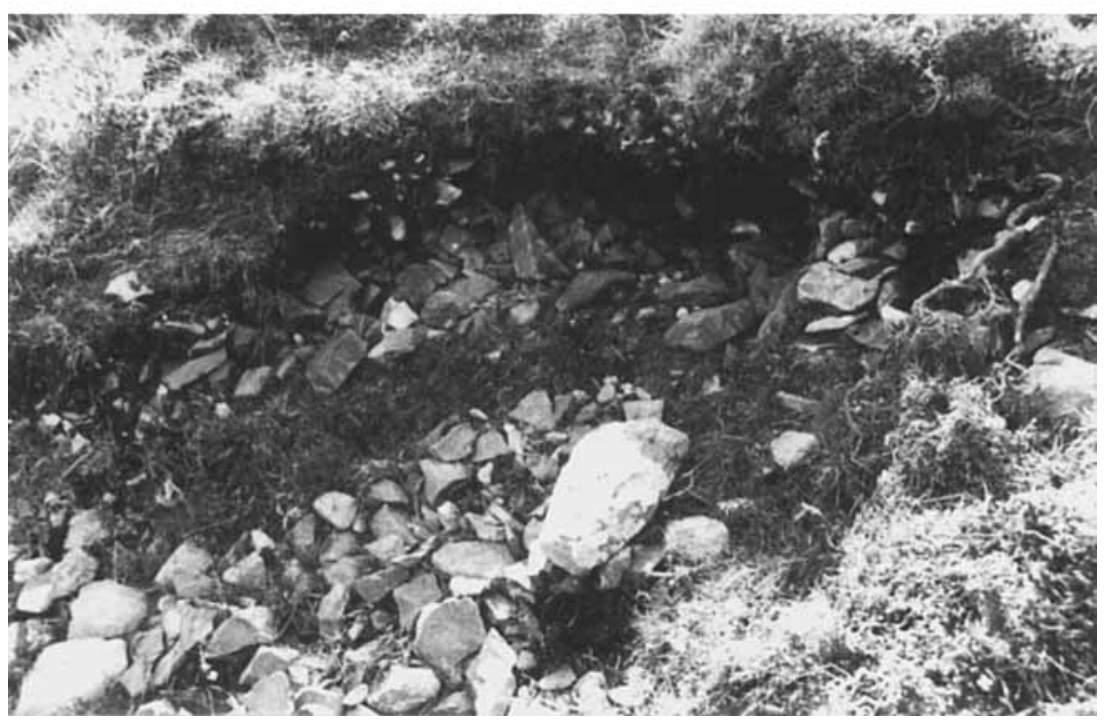

Excavations at the souterrain by Sands in 1875 and by the Kearton brothers in 1896 (Sands 1877: 186-7; Kearton 1897: 13-16) produced several stone implements. Kearton was vague about the context of the finds; his photograph shows $5-7$ broken implements, found 'in digging out and restoring' the souterrain. Sands reported that the local people immediately recognized the implements which he found: "Sean lamhog, sean sgian," old axe, old knife, they said'; he interpreted them as tools for butchering sea birds and livestock. Sands discovered 'a large number of rude stone implements resembling hatchets or wedges' - a) inside the souterrain (the context is unclear); b) 'a number' of them around the 'hole in the roof' ('above the stones and under the soil'); and

c) two in what he interpreted as the souterrain's midden.

The balance of this evidence suggests that at least some of the implements were not part of a recent deposit of field clearance stones; their numbers are greater than would be predicted by the ratio of broken dolerite implements to pieces of granophyre and fire-cracked beach pebbles in clearance dumps visible today. The use period of the implements, then, may coin- 
cide with an 'occupation' phase at the souterrain.

The most obvious parallels for the stone implements are the 'stone shares' made of sandstone, found in Orkney and Shetland in archaeological contexts which range from the Neolithic to the Iron Age (Rees 1979; Rees in Whittle 1986). On Hirta, the range of uses for stone implements would have been relatively limited. Any wood used here would have been driftwood, unless supplies were imported from much further afield; it can hardly have been spared from the Western Isles (Bohnke 1988). Cutting and chopping tools would be needed for butchering domestic animals, seals, whales, etc. and for cutting leather. Many of these uses would require sharp flake tools, rather than the more massive implements which form a substantial part of the St Kilda assemblage as it appears so far. A biologically viable population of 200 or so, depending on say 40 or 50 cultivators using the requisite number of dolerite-tipped 'hoes' in an agricultural system lasting several centuries - perhaps up to two millennia? - would have generated a good deal of quarry waste.

Much has been written about the dependence of St Kildans on sea birds and their eggs in recent centuries, and the feats of skill, cunning and endurance which accompanied the quest for these resources. However, the prehistory of this way of life on the St Kilda archipelago is unknown. On this tiny, vulnerable island, various factors might trigger a shift towards increased dependence on sea birds. The pollen record (Walker 1984) shows that major shifts in climate, including increasing sea spray, had a serious impact on St Kilda's vegetation. There are suggestions that cultivation, properly organized and practised in favourable climatic conditions, could be more rewarding than was apparent in the last days of St Kilda. In the days of Martin Martin (c. 1700) St Kilda had the finest, earliest-ripening barley in the Western Isles, and it was actually exported, at a time when the local population was at its recorded maximum of $c .180$ (Steel 1975: 80); although perhaps Martin's statements about barley yields of between sixteen- and twentyfold (Martin 1698: 18) should be taken (almost literally in this case) with a pinch of salt. A great deal was known about using manure and making compost (see Steel 1975: 81 for a brief summary). In the mid 13th century, Kenneth Macaulay commented on the quality of the grazing and on the quantity and richness of the milk, and the potential of the arable land ("rendered extremely fertile by the singular husbandry of very judicious husbandmen'); he thought that the island should be able to support about 300 people $(1764: 29-30,33-4,196)$. As he shrewdly remarked: 'the inhabitants of St Kilda were much more numerous heretofore, than they are at present. Whether this visible decrease is to be resolved wholly into physical causes, or whether it ought to be imputed to political ones in part, I shall not determine...'

\section{Earlier head-dykes}

The third discovery of my 1994 visit lends some credence to the notion that agriculture may have been well-organized in 'prehistoric' times. On the loose map included with the excellent volume produced by the RCHAMS, The buildings of St Kilda (Stell \& Harman 1988), a number of 'old tracks' are marked in the area on the eastern side of Village Bay, both just above and just below the 1830 head dyke. It seems that this interpretation of the field evidence (Stell \& Harman 1988: 2, 17) is based on the concept - well enough supported in itself - of a pre-1830 village with buildings laid out on two sides of a 'street'. These 'old tracks' consist of narrow linear zones, cleared of stones, running along the hillside. I interpret them, however, as the remains of pre-1830 head dykes, narrow terraces quarried for stone and levelled off, the head dykes being built along their front edges and subsequently abandoned and/or robbed out (FIGURE 3). The RCAHMS plan marks orthostats which remain along these front edges. It is hard to imagine how or why the barefoot and wheel-less early St Kildans would have created these features as 'tracks'. The RCAHMS map marks no plausible destinations for them, they have no recognizable destination at their western ends, and the 'track' which runs behind the Feather Store and the gun at the extreme southeast end of the settlement leads straight on to the clifftop. For much of the eastern sector of the village, the 'old tracks' actually indicate the courses of two pre-1830 head dykes. The original character of the lower of these is not very clear between cleits 163 and 34; it seems to have followed pre-existing irregular bounda- 
ries. That the two old head dykes were successive, with the upper one built later, is shown by the fact that, between cleits 150 and 162, the parcel defined by the upper head dyke was sub-divided, and two at least of the sub-dividing walls slight the flat zone behind the lower head dyke. Furthermore, in the area just above cleits 151 and 152 is at least one old head-dyke course of this kind, which is not marked on the RCAHMS map.

West of cleits 114 and 115 is a wet zone in which peat has been cut and perhaps any stones encountered taken away. Further west, on the other side of Abhainn Mor, the headdyke line is continued by an orthostatic wall running along the contour; it is cut by the modern road about $150 \mathrm{~m}$ north of the point where the road comes through the 1830 head dyke. West of the western sector of the 1830 head dyke there are traces of the course of at least one robbed-out old head dyke, and it is fairly clear that older land enclosure around Village Bay would have incorporated the irregular parcels which run along the western side of the bay as far as Abhainn Ruaival, including the area of the site of St Briannon's church. Land has evidently been lost to the sea here.

Thus it seems that more land in the Bay area was formerly enclosed than was the case in 1830; this land was defined by a head dyke built in part with orthostatic walling after careful quarrying and levelling had taken place. It was mostly a free-standing structure, although in parts, notably above Tobar Childa, above Houses 3 to 6 and on the west side, the head dyke may have been defined by the upper edges of parcels of land already enclosed. In the eastern zone, extending from cleits 10 to 140 , later head dykes were built higher up the slope, again mostly as 'free-standing' structures but also in places taking pre-established parcels into account. It looks very much as if building these head dykes was a communal project to support an evidently well-organized farming system with a strong communal orientation (as was the case for the system which survived into recorded history). These early head dykes, as yet undated, are reminiscent of the inmark/ utmark distinction made by the Scandinavians in Scotland, of the 'ring garths' of Cumbria (Denyer 1991) and the 'Acre Wall' built at the upper edge of the dale-side cow pastures in Upper Swaledale, North Yorkshire, an area of pre-Conquest Norse settlement.

\section{Conclusion}

The dolerite industry supplements the numerous 'boat-shaped structures' beyond the Hirta head dyke in implying the presence of a viable later Bronze Age community on these islands, established sometime in the 2nd millennium $\mathrm{BC}$, although conclusive dating evidence is still awaited. The effect is to strengthen our impression of the competence and confidence of the Bronze Age peoples of northern Scotland in seamanship, craft skills and, not least, social interaction among remote communities separated or linked by large expanses of sea. Further work may establish whether implements of Hirta dolerite were exported, whether the parallels with Orkney and Shetland imply cultural links with the Northern Isles and whether the apparent absence of implements of Hirta dolerite on the Western Isles is confirmed. Specialists in the prehistoric stone-working industries of Scotland, and recent excavators, should consider whether the provenance of all the igneous stone encountered has been satisfactorily accounted for. One or two pieces of worked stone, in good archaeological contexts, could be critical to our understanding of prehistoric cultural connections. It will also be important to find out how late the use of stone persisted on Hirta, allowing its inhabitants to remain independent of imported metalwork as necessary; and when dependence on externally supplied iron tools became established.

Charles Maclean (1977: 23-4) wrote that 'the history of the St Kildans is essentially the story of a bird culture'. Perhaps that is true for most of the period of recorded history. But we now see that the early St Kildans had an organized agrarian landscape long before Neil Mackenzie re-organized it in 1830 , and probably an agrarian system which was in principle sustainable over long time-periods. The recognition of possible earlier 'ring garths' may indicate that the same can be said of the later prehistoric (Norse?) period too. On the Western Isles of Scotland, coastal erosion, the development of the machair and the growth of peat have made it hard to reconstruct the landscape of the late prehistoric and Norse communities which may have been ancestral to the one on Hirta. This small island at the outermost edge of Europe, a place which must always have been socially marginal, may be just the periphегу we need to help us to understand the core. 
Acknowledgements. I wish to thank Alex Morrison and Mark Edmonds for discussing this topic with me, Robin Turner for various kinds of help, Patrick Foster for producing the drawings (those of the implements from my own imperfect origi-

\section{References}

BOHNKE, S.J.P. 1988. Vegetation and habitation history of the Callanish area, Isle of Lewis, Scotland, in H.H. Birks et al. (ed.), The cultural landscape: past, present and future: 445-61. Cambridge: Cambridge University Press.

BRADLEY, R. \& M. EDMONDS. 1993. Interpreting the axe trade. Cambridge: Cambridge University Press.

CoTTAM, M.B. 1979. Archaeology, in A. Small (ed.), A St Kilda handbook: 36-61. Edinburgh: National Trust for Scotland.

DENYER, S. 1991. Traditional buildings in the Lake District. London: Gollancz, Crawley.

EDMONDS, M., A. SHERIDAN \& R. TippiNG. 1992. Survey and excavation at Creag na Caillich, Killin, Perthshire, Proceedings of the Society of Antiquaries of Scotland 122: 77-112.

Hakman, M. 1976-7. An incised cross on Hirt, Harris, Proceedings of the Society of Antiquaries of Scotland 108: 254-8.

KEARTON, R. \& C. KEARTON. 1897. With nature and a camera. London: Cassell.

Macaulay, K. 1764. The history of St Kilda. London: T. Becket.

MACGREGOR, D.R. 1960. The island of St Kilda: a survey of its character and occupance, Scottish Studies 4: 148.

MACLEAN, C. 1977. Island on the edge of the world. Edinburgh: Canongate. nals), Meg Buchanan for allowing me to inspect and photograph the stone implements excavated on St Kilda in the Kelvingrove Museum (Glasgow) and Mireille Fleming for developing and printing my photographs.

Martin, M. 1698. A late voyage to St Kilda, the remotest of all the Hebrides. London: D. Brown \& D. Goodwin. REes, S. 1979. Agricultural implements in prehistoric and Roman Britain. Oxford: British Archaeological Reports. British series 69 .

SANDS, J. 1877. Notes on the antiquities of the island of St. Kilda, Proceedings of the Society of Antiquaries of Scotland 12: 186-92.

STEEL, T. 1975. The life and death of St Kilda. Glasgow: Fontana/Collins.

STELL, G.P. \& M. HARMAN, 1988. Buildings of St Kilda. Edinburgh: RCAHM (Scotland).

Sutherland, D.G., C.K. Ballantyne \& M.J.C. Walker. 1984. Late Quaternary glaciation and environmental change on St Kilda, Scotland, and their palaeoclimatic. significance, Boreas 13: 261-72.

WALKER, M.J.C. 1984. A pollen diagram from St Kilda, Outer Hebrides, Scotland, New Phytologist 97: 99113.

WhitTLE, A. 1986. Scord of Brouster, an early agricultural settlement on Shetland. Oxford: Oxford University Committee on Archaeology.

WICKHAM JONES, G.R. 1986. The procurement and use of stone for flaked tools in prehistoric Scotland, Proceedings of the Society of Antiquaries of Scotland 116:110.

Williamson, K. \& J.M.BoYD. 1960. St Kilda summer. London: Hutchinson. 